\title{
133. IVP検査による腎機能定量化分析の簡易的方法
}

A simple methed of renal fanction quantitative analysis of the intravenous pyelography

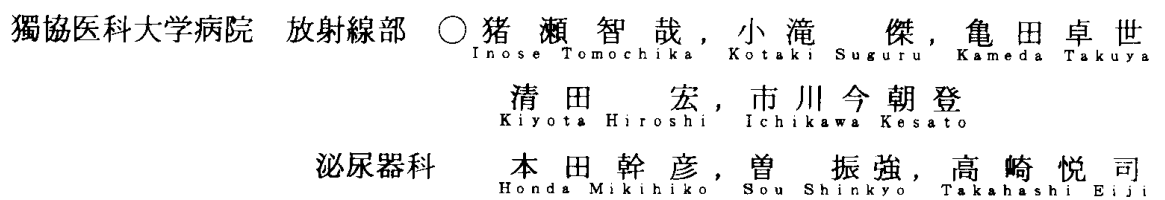

〔目的】従来から I V P 検査法に拈いて腎機能測定は，濃度計による多数 point 測定法等により行なわ れているが，繁雑性，再現性等により問題は多く，日常ルーチン恰査法として確立されていない。そ こで今回我々は，日常ルーチン検查法として充分に対応することのできる，濃度特性チャート測定に よる簡素化した方法でのＩＶP腎機能定量的評価分析を試みた結果，有用であったので報告します。

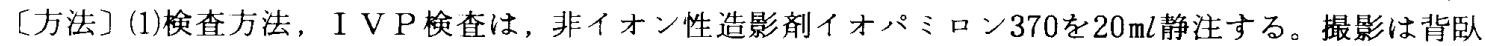
位にて静注前 $(0 \mathrm{~min})$ ，静注開始より $5 \mathrm{~min}, 15 \mathrm{~min}$ ，(必要により $30 \mathrm{~min} ， 60 \mathrm{~min}$ ）にて行った。

(2)評価方法，(1)モーニングチェッカー装置による濃度特性チャートフィルムを作成し，検査用增感紙 にセットする。これを検査と共に撮影記録させ，経時的撮影に拈ける撮影条件の変化に伴う濃度バラ ツキ補正用として使用する。(2)被写体の大きさ，厚さ等の補正用として，管電圧一定に拉ける $\mathrm{mAs}$, エネルギー変化による濃度補正用特性チャートを作成した。特性チャートは 6 種類（A〜F），Bstep チャートを基準に濃度補正する。(3)左右の腎血を測定部位とし，濃度特性チャートにより簡易濃度数 值を読み取り，その数值をもとに簡易的評価での IVP 検査数值測定分析を行なった。(4)〈方法(1)(2) (3)〉により，簡易的濃度数值評価による(i)腎孟掑取能(ii)腎孟排泄能(iii)レノグラム的評価分析(iv) 以上の
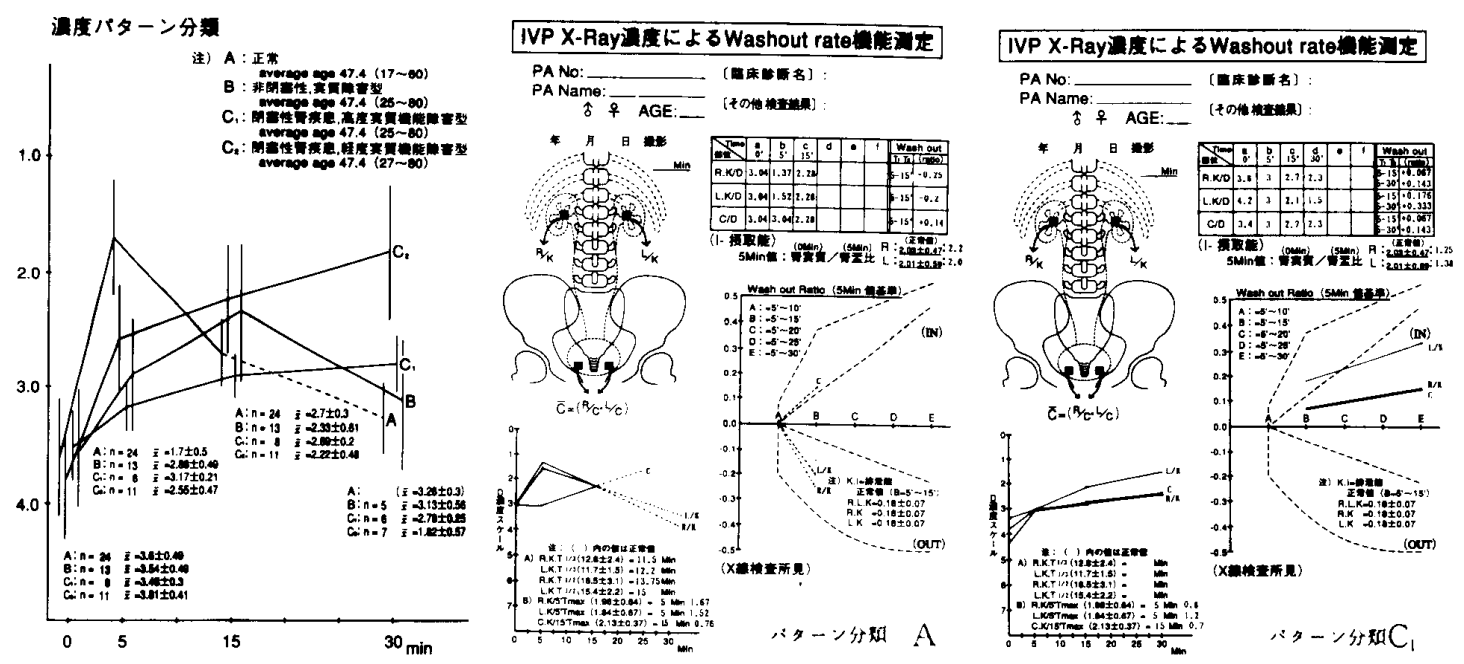

評価を 30 例試み, 病態別濃 度機能パターン分類を試み た。(5)〈方法(4)〉の結果を基 に,臨床的定量化を目的と して，腎機能生化学検查の $\mathrm{Cr}$ (クレアチニン), $\mathrm{Ccr}$ (クレ アチニンクリアランス)值 との相関分析評価を試みた。 [結果]図参照。Cr及びC cr との相関も認められた。
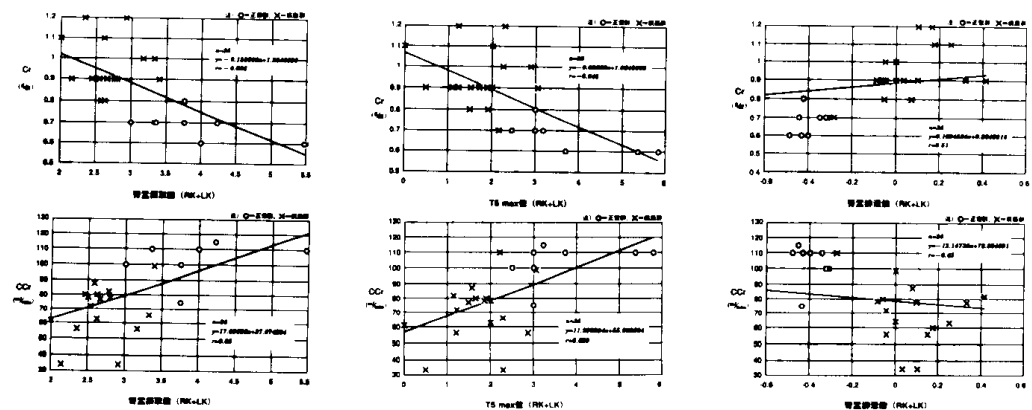

[まとめ]今回我々が試みた日常ルーチン検查であるIVP 検查に拉いて, 簡易的特性チャート濃度測 定法は，従来の力法に比較して，簡単に，ょり精度良く，腎機能の定量化分析による病態評価及び左 右分腎機能評価，パターン化分類による重症度評価が，ある程度可能となった。 